\title{
PEMBUATAN SILASE BERBAHAN DASAR BIOMAS TANAMAN JAGUNG
}

\author{
ACTIVITIES OF MAKING SILAGE USING CORN BIOMASS \\ ${ }^{1)}$ Muhammad Sayuti, ${ }^{2)}$ Fahrul Ilham, ${ }^{3)}$ Tri Ananda Erwin Nugroho \\ ${ }^{1,2,3)}$ Program Studi Peternakan, Universitas Negeri Gorontalo \\ Jalan Jenderal Sudirman No 6 Kota Gorontalo, 96128 \\ Email: m.saym@yahoo.co.id, fahrulilham82@ung.ac.id
}

\begin{abstract}
ABSTRAK
Silase merupakan hijauan makanan ternak yang diawetkan dengan cara disimpan dalam silo anaerob. Pengabdian Pada Masyarakat (PPM) ini dilakukan di Desa Timbuolo Tengah Kecamatan Botupinge Provinsi Gorontalo dengan tujuan menambah pengetahuan dan keterampilan warga desa membuat pakan awetan silase. Metode yang digunakandemonstrasi dan eksperimen yaitu pemberian teori dan simulasi kepada mitra sasaran, dilanjutkan dengan praktek pembuatan silase. Lama kegiatan sejak pemberian teori hingga proses fermentasi selesai adalah 21 hari. Evaluasi kualitas produk silase berdasarkan penampilan fisik, kimia, dan respon ternak sapi yang diberi silase.Evaluasi perilaku mitra diketahui melalui respon yang diberikan selama proses pelatihan maupun setelah kegiatan pengabdian dilaksanakan. Berdasarkan hasil pengamatan terhadap respon mitra sejak awal hingga berakhirnya kegiatan pengabdian,pelatihan pembuatan silase berhasil menambah pengetahuan dan keterampilan peternak sapi di Desa Timbuolo Tengah. Kualitasfisik silase yang dihasilkan cukup baik ditandai dengan bau wangi sedikit asam, rasa sedikit asam dan agak manis, warna hijau kekuningan, tekstur kering dan terasa empuk, pH 4.09. Silase yang diberi starter EM-4 selama fermentasi memiliki kualitas kimia yang lebih baik dibandingkan dengan tanpa pemberian starter dengan kandungan protein 8,34\% dan serat kasar 26,94\%. Respon ternak yang diberi silase cukup baik.Silase sebaiknya diangin-anginkan terlebih dahulu sebelum diberikan ke ternak sapi dan pemberiannya dilakukan secara bertahap hingga ternak sapi dapat menyukai sepenuhnya.
\end{abstract}

Kata kunci: Jagung; Sapi Potong; Silase

\begin{abstract}
Silage is a preserved forage that is stored in silo in an anaerobic condition. The community service activities was conducted in Middle Timbuolo village, sub-district of Botupingge, Province of Gorontalo with the purpose was to improve the knowledge and skills of the villagers in making silage. The methods used were demonstration and experiment by giving some theories and simulation to the villagers and the target group members and then continued by practicing in making the silage directly. The activities was conducted for 21 days, started from the theory administration until the fermentation was finished. The quality of silage was evaluated based on the physical and chemical appearance and the response of the cattle that given silage. Evaluation on partner's behaviour known through their response during the training process and after the service activities were carried out. Based on the results, it showed that the training had been successfully improved the knowledge and skills of the cattle raiser in Middle Timbuolo village. The physical quality of silage that had been produced was quite good characterized by the fragrant odor that was slightly wry and the taste that was rather sweet but slightly acidic, yellowish green color, dry and softy texture and the pH 4.09. Chemically, the silage that was given an EM-4 starter during fermentation had better quality compared to the silage not given the starter in which the protein content was $8.34 \%$ and the crude fiber was $26.94 \%$. The cattle response after given silage was quite good. Before being fed to the cattle, the silage should be aerated in advance and the administration should be carried out gradually until the cattle can fully like it.
\end{abstract}

Keywords: Corn; Beef Cattle; Silage 


\section{PENDAHULUAN}

Desa Timbuolo Tengah yang terletak di Kecamatan Botupingge, Kabupaten Bone Bolango, Provinsi Gorontalo memiliki potensi di bidang pertanian dan peternakan. Sebagian wilayah desa ini terletak di pinggir sungai Bone sehingga wilayah sekitarnya cukup subur untuk tanaman pertanian maupun pakan untuk ternak sapi, namun sebagian besar wilayah desa Timbuolo Tengah terletak di pegunungan dan perbukitan, dan akses untuk mendapatkan air tanah cukup sulit terutama di musim kemarau. Berdasarkan hasil wawancara dengan warga setempat, kedalaman sumur yang harus digali untuk mendapatkan air tanah di daerah perbukitan adalah minimal 10 meter.

Silase merupakan pakan yang diawetkan dengan cara difermentasi dalam silo pada kondisi anaerob (Ilham \& Mukhtar, 2018). Kualitas nutrisi silase tidak dapat sama dengan hijauan yang masih segar, namun pengawetan pakan dengan cara ensilase dapat menambah daya simpan hijauan dengan tingkat kehilangan nutrisi yang lebih kecil bila dibandingkan dengan hanya dibiarkan saja dalam suhu ruang. Prinsip pembuatan silase adalah mempertahankan kondisi kedap udara dalam silo semaksimal mungkin agar bakteri dapat menghasilkan asam laktat untuk membantu menurunkan $\mathrm{pH}$, mencegah oksigen masuk kedalam silo, menghambat pertumbuhan jamur selama penyimpanan (Hidayat, 2014). Proses fermentasi silase umumnya berlangsung selama 21 hari, setelah itu silase sudah bisa digunakan sebagai pakan sapi dalam bentuk pakan komplit atau disimpan dalam waktu yang lama jika belum digunakan (Adriani, Fatati, \& Suparjo, 2016).
Permasalahan yang dihadapi mitra adalah keterbatasan pengetahuan tentang cara menambah daya simpan hijauan makanan ternak disaat produksinya berlimpah. Saat musim hujan, hijauan makanan sapi potong di desa Timbuolo Tengah dan sekitarnya cukup berlimpah, namun di musim kemarau ketersediaannya tidak mampu memenuhi seluruh kebutuhan sapi potong setempat.Akibatnya produktivitas sapi potong tidak bisa maksimal sebab pakan yang dikonsumsi tidak cukup untuk memenuhi kebutuhan untuk produksi dan bereproduksi. Beberapa peternak bahkan melepas ternaknya untuk merumput dipinggir jalan hingga memasuki lahan kebun dan pekarangan warga sehingga menimbukan protes dari warga lain maupun beberapa pengendara yang melewati jalan desa.

Dalam rangka mengatasi permasalahan mitra, maka diperlukan pelatihan tentang pengawetan hijauan makanan ternak dengan metode silase bagi warga Desa Timbuolo Tengah. Kegiatan pengabdian melalui pelatihan ini bertujuan untuk menambah pengetahuan dan keterampilan warga desa dalam membuat pakan awetan silase. Melalui kegiatan ini diharapkan warga desa tidak kesulitan lagi untuk mendapatkan pakan segar terutama di saat kemarau sebab persediaan pakan dalam bentuk silase dapat disimpan untuk jangka waktu beberapa minggu bahkan beberapa bulan dengan kualitas yang tidak berbeda jauh dari pakan segar.

\section{METODE}

Mitra yang menjadi peserta pada kegiatan Pengabdian Pada Masyarakat (PPM) ini adalah adalah warga desa Timbuolo Tengah Kecamatan Botupingge, Kabupaten Bone Bolango yang tergabung dalam Kelompok Ternak Polooma. Jumlah peternak yang menjadi anggota kelompok adalah 10 orang, dan 
setiap anggota kelompok memiliki sapi potong jenis sapi bali. Selain anggota kelompok ternak Polooma, ikut pula beberapa warga desa diluar anggota kelompok yang berprofesi peternak danmemiliki ketertarikan untuk mempelajari cara pembuatan silase.

Metode yang digunakan adalah pelatihan dengan tahapan:

1. Identifikasi permasalahan mitra. Kegiatan ini berupa wawancara dengan mitra tentang potensi dan permasalahan yang dihadapi dan dilanjutkan dengan kunjungan ke lapangan untuk melihat langsung permasalahan mitra

2. Sosialisasi program yang dilakukan terhadap Kepala Desa Timbuolo Tengah dan anggota kelompok mitra. Tujuan sosialisasi adalah memberikan penjelasan tentang tujuan dan bentuk kegiatan yang akan dilakukan serta hal-hal yang perlu dipersiapkan saat pelaksanaan pelatihan

3. Penyuluhan tentang cara pembuatan silase berbahan dasar biomass jagung. Materi yang diberikan adalah pengertian silase, alat dan bahan yang digunakan, cara pembuatannya, dan cara pemberian pada ternak

4. Pembuatan silase, yaitu praktek langsung pembuatan silase yang dilakukan bersama warga desa. Bahan utama silase yang dibuat adalah daun jagung, dedak padi, molases, Effective Microorganism (EM)-4 untuk peternakan, dan air. Peralatan yang digunakan antara lain sekop, parang, terpal, tong biru, ember, mesin chopper.

5. Evaluasi program. Setelah seminggu, kualitas fisik silase dievaluasi apakah telah memenuhi kriteria silase yang baik. Evaluasi kualitas kimiawi dari silase dilakukan dengan mengirimkan sampel ke Laboratorium Kimia dan Makanan Ternak, Universitas
Hasanuddin untuk dianalisis

kandungan proksimatnya.

\section{HASIL DAN PEMBAHASAN}

\section{Identifikasi PermasalahanMitra}

Kegiatan ini dilakukan dengan melakukan kunjungan ke lokasi pengabdian dan wawancara dengan mitra. Hasil pengamatan dan wawancara diperoleh informasi tentang beberapa potensi yang dimiliki oleh mitra dan permasalahan yang dihadapi.Salah satu permasalahan utama mitra adalah ketidakmampuan untuk menyediakan hijauan pakan yang berkualitas sepanjang waktu dan hal ini berdampak pada produktivitas ternak yang dimiliki tidak bisa optimal. Pengetahuan sebagian anggota mitra tentang pengawetan pakan dengan cara silase hanya diperoleh dari pembicaraan antar sesama warga, namun pelatihan dan praktik langsung cara membuat silase dari biomas tanaman jagung belum pernah diperoleh.

\section{Sosialisasi Program}

Hasil identifikasi permasalahan selanjutnya didiskusikan oleh Tim pelaksana untuk merumuskan dan merancang solusi yang akan dilakukan dalam rangka mengatasi permasalahan mitra. Potensi dibidang pertanian Desa Timbuolo Tengah adalah tanaman jagung sehingga silase yang akan dibuat menggunakan bahan dasar biomass tanaman jagung. Rancangan solusi yang akan dilakukan selanjutnya di sosialisasikan kepada mitra dan Kepala Desa Timbuolo Tengah. Tujuan sosialisasi adalah memberikan penjelasan tentang tujuan dan bentuk kegiatan yang akan dilakukan serta hal-hal yang perlu dipersiapkan saat pelaksanaan pelatihan.

Penyuluhan Silase dan
Pembuatan Sara
Biomass Jagung.


Penyuluhan dalam bentuk ceramah dan diskusi tentang teori seputar silase dan cara pembuatannya dilakukan di Aula Kantor Desa Timbuolo Tengah. Kegiatan ini dibuka langsung oleh Camat Botupingge dan didampingi oleh Kepala Desa Timbuolo Tengah. Beberapa peserta yang hadir adalah anggota kelompok ternak Polooma, warga Desa Timbuolo Tengah, dan beberapa perwakilan warga dari Desa tetangga (Desa Timbuolo Timur). Selama penyuluhan, para peserta terlihat sangat antusias mengikuti setiap tahapan dan terlihat adanya pertanyaan yang diajukan oleh para peserta.

\section{Pembuatan Silase}

Kegiatan ini berupa praktek langsung pembuatan silase dengan bahan utama biomass tanaman jagung yang dilakukan bersama anggota kelompok ternak dan beberapa warga Desa Timbuolo Tengah yang tertarik untuk mengetahui cara pembuatan silase. Selama kegiatan praktek, seluruh peserta aktif untuk bekerjasama dalam membuat silase sejak persiapan alat dan bahan, pelaksanaan, dan penyimpanan. Seluruh peserta juga mengajukan beberapa pertanyaan untuk mengetahui lebih mendalam lagi tentang fungsi dan kegunaan dari beberapa bahanbahan yang akan digunakan untuk membuat silase.

Alat yang digunakan untuk membuat silase diantaranya adalah silo dari tong biru ukuran 300 liter sebanyak 2 buah, mesin pemotong rumput (chopper), timbangan gantung dan timbangan duduk, terpal, kantong plastic. Bahan-bahan yang digunakan adalah bahan yang ketersediaannya mudah diperoleh disekitar lokasi, murah, dan tidak mengandung bahan berbahaya bagi ternak sapi. Bahan yang digunakan, antara lain:

1. Biomas jagung, yaitu seluruh bagian dari tanaman jagung kecuali akar yang dapat dimanfaatkan sebagai makanan sapi. Umur tanaman jagung dalam kegiatan ini adalah 2 bulan dengan ciri utama buah jagung yang masih muda.
2. Urea, yaitu pupuk kimia mengandung Nitrogen $(\mathrm{N})$ berkadar tinggi. Urea berbentuk butir-butir kristal berwarna putih dengan rumus kimia $\mathrm{NH}_{2} \mathrm{CONH}_{2}$. Urea mudah larut dalam air dan sangat mudah menghisap air (higroskopis). Urea mengandung unsur hara $\mathrm{N}$ sebesar $46 \%$ dengan pengertian setiap $100 \mathrm{~kg}$ mengandung $46 \mathrm{Kg}$ Nitrogen, Moisture 0,5\%, Kadar Biuret 1\%, ukuran 1-3,35MM 90\% Min serta berbentuk Prill (Pusri, 2018).

3. Molases (tetes tebu). yaitu hasil samping dari pengolahan tebu menjadi gula yang masih mengandung gula dan asam-asam organik cukup tinggi. Kandungan sukrosa dalam molases adalah 48-55\% (Sebayang, 2006) sehingga sering digunakan peternak untuk sumber makanan mikrorganisme dalam proses pembuatan pakan fermentasi.

4. Dedak Padi, yaitu hasil samping darihasil penggilingan padi menjadi produk beras atau bagian luar (kulit ari) beras yang dibuang pada waktu dilakukan pemutihan beras. Dedak padi halus memiliki kandungan protein $11,35 \%$, lemak $12,15 \%$, karbohidrat $28,62 \%$, abu $10,5 \%$, serat kasar $24,46 \%$ dan air $10,15 \%$. Selama proses fermentasi, selain menjadi sumber makanan bagi mikroba didalam silo, dedak padi juga dapat meningkatkan palatabilitas dan daya cerna ternak sapi terhadap silase.

5. Effective Microorganism (EM)-4. EM-4 merupakan cairan yang berwarna coklat kekuning-kuningan yang berisi berbagai macam mikroorganisme yang menguntungkan hasil fermentasi dari bahan-bahan organik. Mikroorganisme dalam EM-4 berupa bakteri seperti bakteri fotosintetik, bakteri asam laktat, actinomicetes, ragi, dan jamur fermentasi. Penambahan EM-4 dalam silase diharapkan dapat mempercepat 
dan meningkatkan kualitas silase selama proses fermentasi.

Komposisi bahan silase yang dibuat terdiri atas biomas tanaman jagung 100 $\mathrm{kg}$, urea $0,25 \mathrm{~kg}$, molases $0,4 \mathrm{~kg}$, dedak padi $0,5 \mathrm{~kg}$, dan starter (Tabel 1). Cara pembuatan silase dilakukan dengan terlebih dahulu melayukan biomas jagung selama 1 hari di ruang terbuka dibawah atap agar kandungan airnya berkurang. Selanjutnya tanaman jagung dipotong potong 3-5 $\mathrm{cm}$ menggunakan mesin pemotong rumput(chopper) dengan tujuan untuk memudahkan pencampuran seluruh bahan sebelum dimasukkan kedalam silo. Pemotongan juga bertujuan agar seluruh bahan hijauan dapat lebih mudah dan dan lebih padat ketika akan dimasukkan ke dalam silo. Potongan biomas jagung selanjutnya ditaburi dengan dedak padi dan dicampur hingga merata

Tabel 1. Komposisi Bahan Penyusun Silase Setiap Silo

\begin{tabular}{ccccccc}
\hline \multirow{2}{*}{ Silo } & Perlakuan & \multicolumn{5}{c}{ Komposisi Silase } \\
\cline { 3 - 6 } & Hanpa starter & Jagung $(\mathbf{k g})$ & Urea $(\mathbf{k g})$ & $\begin{array}{c}\text { Molases } \\
(\mathbf{k g})\end{array}$ & $\begin{array}{c}\text { Dedak padi } \\
(\mathbf{k g})\end{array}$ & Starter $(\mathbf{m l})$ \\
\hline 1 & Tand & 100 & 0,25 & 0,4 & 0,5 & \\
2 & Dengan starter EM-4 & 100 & 0,25 & 0,4 & 0,5 & 81,6 \\
\hline
\end{tabular}

Urea yang telah ditimbang selanjutnya dicampur dengan air dalam ember hingga seluruhnya larut dalam air. Setelah urea larut dalam air, molases yang telah ditimbang juga dimasukkan kedalam ember dan diaduk rata. Bahan terakhir yang dimasukkan ke dalam ember adalah EM-4 untuk peternakan, kemudian diaduk hingga larut dan tercampur rata. Campuran urea, molases, EM-4, dan air selanjutnya disiramkan ke campuran biomas tanaman jagung dan dedak padi dengan cara dipercik sedikit demi sedikit. Setelah dipercik, campuran biomas jagung diaduk kembali hingga seluruh bahan tercampur merata dan dimasukkan ke dalam silo sedikit demi sedikit sambil dipadatkan dengan cara diinjak-injak. Setelah penuh dengan biomas tanaman jagung, silo ditutup rapat dan diinkubasi dalam kondisi anaerob selama satu minggu dibawah naungan. Seminggu setelahfermentasi, silase dibuka dan dilakukan evaluasi terhadap kualitas dengan berdasarkan penampilan fisik kualitatif.

\section{Evaluasi Kegiatan}

Evaluasi merupakan suatu proses untuk melihat ketercapaian program apakah sesuai dengan tujuan awal program (Sulistyawati, et all, 2019). Evaluasi terhadap kegiatan pengabdian ini berdasarkan pengamatan terhadap perilaku mitra dan kualitas produk silase yang dihasilkan (fisik, kimia, dan kesukaan ternak terhadap silase).

\section{Evaluasi Perilaku Mitra}

Berdasarkan hasil pengamatan terhadap perilaku mitra, pengetahuan dan keterampilan mitra bertambah dengan adanya kegiatan pengabdian ini. Hal tersebut terlihat dari beberapa indikator diantaranya respon mitra yang cukup antusias dan banyak mengajukan pertanyaan selama proses pembuatan hingga semua tahapan kegiatan telah selesai dilaksanakan. Hasil wawancara sebelum pelaksanaan pelatihan terhadap beberapa anggota mitra menyatakan bahwa umumnya para peserta hanya pernah mendengar istilah pengawetan pakan dengan cara silase namun melihat dan terlibat langsung dalam proses pembuatannya tidak pernah. Setelah semua tahapan pembuatan silase 
dilaksanakan, seluruh anggota mitra menyatakan merasa cukup puas dengan kegiatan pengabdian dan tertarik untuk membuat silase pakan secara mandiri.Antusias warga untuk menyiapkan pakan berkualitas juga terlihat dengan adanya beberapa warga desa dari anggota mitra yang sudah mulai melakukan penanaman rumput gajah pada lahan lahan yang tidak terpakai, sehingga ketika produksinya berlimpah sebagian dapat diawetkan dalam bentuk silase.

\section{Evaluasi Kualitas Fisik Produk}

Evaluasi terhadap kualitas fisik silase diketahui dengan cara mengeluarkan sampel silase dari dalam silo setelah satu minggu. Sebelum dievaluasi, silase terlebih dahulu diangin-anginkan agar bau amoniak bawaannya dapat berkurang sehingga lebih mudah diidentifikasi. Indikator-indikator penilaian terhadap kualitas fisik dari silase yang diamati berdasarkan Ilham \& Mukhtar (2018) yaitu bau/wangi, rasa, warna, tekstur, dan $\mathrm{pH}$.

Berdasarkan hasil pengamatan diperoleh bau silase biomas tanaman jagung yang dibuat adalah bau sangat wangi seperti buah-buahan, sedikit asam, dan terdorong untuk mencicipi. Bau asam yang ditimbulkan akibat aktivitas bakteri asam laktat yang mencerna selulose, pati, gula, protein, dan lemak dalam biomas tanaman jagung menyebabkan bakteri asam laktat tumbuh semakin subur dan kondisi dalam silo juga semakin asam.Bau wangi yang timbul pada silase disebabkan adanya fermentasi asam propionat sehingga menimbulkan wangi yang menyengat (Saun dan Heinrichs, 2008). Hasil ini termasuk sangat baik sebab silase yang kurang baik memiliki ciri bau yang tidak sedap seperti kompos, serta memiliki jamur.

Berdasarkan indikator penilaian rasa, silase yang dibuat ketika dicoba terasa asam sedikit dan agak manis. Rasa asam tersebut disamping karena faktor bakteri asam laktat, juga dikarenakan bahan tambahan molases sehingga ketika dicium baunya terasa sedikit manis. Silase yang kurang baik ditandai dengan ciri rasa yang tidak sedap serta tidak ada dorongan untuk mencoba.

Berdasarkan indikator penilaian warna, silase yang dibuat terlihat berwarna hijau kekuningan. Warna tersebut menandakan bahwa silase yang dibuat tidak terlalu jauh menyimpang dari warna biomass tanaman jagung ketika masih dalam keadaan segar. Silase yang kurang baik ditandai dengan terjadinya perubahan warna menjadi hitam mendekati warna kompos akibat temperatur silase dalam silo yang terlalu tinggi. Hasil penelitian Kushartono \& Nani (2015) menyatakan silase yang baik apabila warna daun masih kehijauan dan tercium bau asam. Reksohadiprodjo (1988) menyatakan perubahan-perubahan yang terjadi dalam tanaman karena proses respirasi aerobik yang berlangsung selama persediaan oksigen masih ada, sampai gula tanaman habis. Gula akan teroksidasi menjadi $\mathrm{CO} 2$ dan air, dan terjadi panas hingga temperatur naik. Bila temperatur tak dapat terkendali, silase akan berwarna coklat tua sampai hitam.

Berdasarkan indikator penilaian tekstur, silase yang dibuat memiliki tekstur kering, tetapi apabila dipegang terasa lembut dan empuk. Apabila menempel ditangan karena baunya yang wangi, tidak dicucipun tidak apa-apa. Kriteria ini sudah cukup baik, sebab tekstur silase yang kurang baik dicirikan kandungan airnya banyak, terasa basah sedikit (becek) bau yang menempel ditangan harus dicuci dengan sabun supaya baunya hilang.

Berdasarkan indikator penilaian $\mathrm{pH}$, silase yang dibuat pada pengabdian inimemiliki nilai $\mathrm{pH}$ 4.09. Hasil penelitian Naibaho, Despal \& Idat (2017) pada silase ransum komplit berbasis jerami dan tebon jagung diperoleh nilai $\mathrm{pH} \quad 3,5$ dan termasuk kategori baik. $\mathrm{pH}$ silase yang rendah dapat mencegah tumbuhnya 
bakteri pembusuk yang yang dapat merusak kualitas silase.

\section{Evaluasi Kualitas Kimia Produk}

Silase yang dibuat di Desa Timbuolo Tengah ada 2 macam perlakuan yaitu dengan tanpa penambahan starter dan dengan penambahan starter EM-4. Berdasarkan hasil analisis proksimat di Laboratorium Kimia dan Makanan Ternak Fapet UNHAS,kandungan protein silase yang diberi starter EM-4 Peternakan adalah $8,34 \%$ lebih tinggi dibanding dengan silase yang tidak ditambah starter yaitu hanya mencapai $7,49 \%$. Demikian pula kandungan Serat Kasar (SK) silase yang diberi starter EM-4 Peternakan lebih rendah dibanding silase yang tidak ditambah starter yaitu $29,5 \%$. Nilai nutrisi protein yang lebih tinggi dan SK yang lebih rendah disebabkan oleh jumlah bakteri yang melakukan proses ensilase didalam silo lebih banyak dibandingkan dengan tanpa penambahan starter sehingga proses ensilase dapat berjalan efektif dan lebih maksimal. Bakteri yang dominan selama proses ensilase adalah Bakteri Asam Laktat (BAL), yang berperan merubah gula menjadi asam laktat. Perubahan ini menyebabkan suasana dalam silo menjadi asam, sehingga menghambat perkembangan beberapa bakteri patogen penyebab terjadinya pembusukan hijauan dalam silo. Suasana asam juga menyebabkan kondisi dalam silo menjadi anaerob dan semakin memperlambat proses respirasi hijauan sehingga tetap awet selama penyimpanan.

Tabel 2. Kandungan Nutrisi Silase Hasil Kegiatan Pengabdian di Desa Timbuolo Tengah

\begin{tabular}{llcccccc}
\hline \multirow{2}{*}{ No } & Perlakuan & \multicolumn{7}{c}{ Kandungan $(\%)$} \\
\cline { 3 - 7 } & & Air & Protein & Lemak & SK & BETN & Abu \\
\hline 1 & Tanpa Starter & 13.69 & 7.49 & 3.06 & 29.5 & 49.29 & 10.66 \\
2 & Penambahan EM-4 & 17.43 & 8.34 & 3.16 & 26.94 & 51.15 & 10.41 \\
\hline
\end{tabular}

\section{Evaluasi Tingkat Kesukaan Ternak}

Evaluasi terhadap produk silase yang dihasilkan dalam kegiatan pengabdian ini dengan memberikannya kepada ternak sapi untuk mengetahui tingkat kesukaan. Hasil pengamatan terlihat ternak sapi menyukai pakan silase yang diberikan dan hal tersebut juga terlihat dari pakan silase yang diberikan seluruhnya habis dimakan tanpa ada yang tersisa.Pemberian silase pada sapi potong sebagai pakan ternak harus mempertimbangkan palatabilitasnya (daya suka). Aroma dan rasa silase adalah khas asam, sehingga tidak semua ternak akan langsung menyukainya. Pengambilan silase dari dalam silo harus dilakukan cepat dan segera ditutup agar udara tidak masuk. Sebelum diberikan pada ternak silase diangin-anginkan terlebih dahulu, agar amoniak yang terbentuk selama proses fermentasi dapat terbuang. Ternak yang belum terbiasa makan silase, pemberian dilakukan sedikit-sedikit dicampur dengan hijauan segar dan dikurangi secara bertahap. Sapi potong yang sudah terbiasa mengkonsumsi silase dapat diberikan $100 \%$ sesuai dengan kebutuhan ternak setiap hari yaitu $10 \%$ dari bobot badan sapi (Adriani, Fataati \& Suparjo, 2016). 


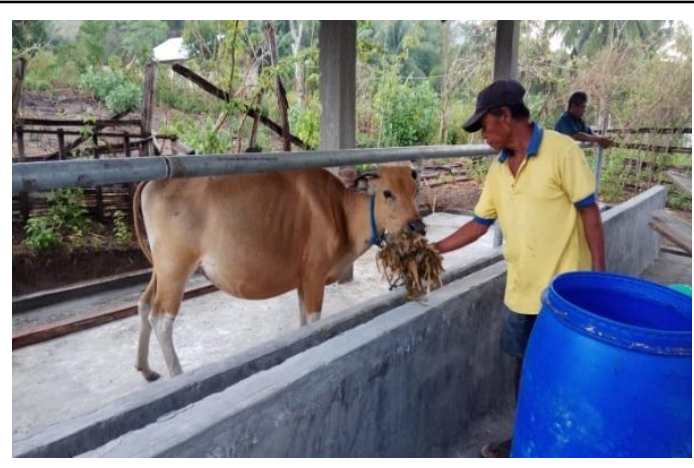

Gambar 1. Pemberian Silase Pada Sapi Bali di Desa Mitra

\section{SIMPULAN}

Pelatihan pembuatan silase mampu menambah pengetahuan dan keterampilan peternak sapi di Desa Timbuolo Tengahdalam pengawetan pakan dalam rangka menanggulangi kekurangan hijauan pakan di musim kemarau. Secara fisik silase yang baik ditandai dengan bau wangi sedikit asam, rasa sedikit asam dan agak manis, warna hijau kekuningan, tekstur kering dan terasa empuk, $\mathrm{pH} 4,09$. Secara kimia, silase yang diberi starter EM-4 selama fermentasi memiliki kualitas yang lebih baik dibandingkan dengan tanpa pemberian starter dengan kandungan protein $8,34 \%$ dan serat kasar $26,94 \%$. Respon Ternak sapi yang diberi produk silase adalah cukup menyukai.Sebelum diberikan ke ternak, silase sebaiknya diangin-anginkan terlebih dahulu dan pemberiannya dilakukan secara bertahap hingga ternak sapi dapat menyukai sepenuhnya.

\section{DAFTAR PUSTAKA}

Adriani., Fatati., \& Suparjo. 2016. Aplikasi Pakan Fermentasi Berbasis Hijauan Lokal Padapeternakan Sapidi Kecamatan Geragai Kabupaten Tanjung Jabung Timur. Jurnal Pengabdian Pada Masyarakat, 31 (3).

Hidayat, N., (2014). Karakteristik Dan Kualitas Silase Rumput Raja Menggunakan Berbagai Sumber
Dan Tingkat Penambahan Karbohidrat Fermentable. Jurnal Agripet, 14 (1).

Ilham, F., \& Muhammad, M. (2018). Perbaikan Manajemen Pemeliharaan Dalam Rangka Mendukung Pembibitan Kambing Kacang Bagi Warga Di Kecamatan Bone Pantai Kabupaten Bone Bolango. Jurnal Pengabdian Kepada Masyarakat (JPKM), 3 (2), 143-156

Kushartono, B., \& Nani, I. (2005). Silase Tanaman Jagung Sebagai Pengembangan Sumber Pakan Ternak. Prosiding, Temu Teknis Nasional Tenaga Fungsional Pertanian.

Naibaho, T., Despal., \& Idat, G.P. (2017). Perbandingan Silase Ransum Komplit Berbasis Jabon Dan Jerami Untuk Meningkatkan Ketersediaan Pakan Sapi Perah Berkualitas Secara Berkesinambungan. Buletin Makanan Ternak, 104 (2),12 - 20

Pupuk Sriwidjaja (Pusri) Palembang. 2018. Pupuk Urea. http://www.pusri.co.id/ina/ureatentang-urea/. Didownload pada 20/7/2018

Reksohadiprodjo, S., (1998). Pakan Ternak Gembala. Yogyakarta: BPFE

Sebayang, F. (2006). Pembuatan Etanol Dari Molase Secara Fermentasi Menggunakan Sel Saccharomyces Cerevisiaeyang Terimobilisasi Pada Kalsium Alginat. Jurnal Teknologi Proses. 68-74.

Saun, R.J.V. \& A.J. Heinrichs. (2008). Troubleshooting Silage Problems: How To Identify Potential Problem. Proceddings of the Mid-Atlantic Conference; Pennsylvania, $26-26$ May 2008. Penn State's Collage. pp. $2-10$. 
Sulistyawati., Muchsin, M., Fatwa, T., Surahma, A. M., Tri, W. S. (2019). Pendampingan Pembuatan Sistem Hidroponik Dan Pengolahan Sampah Organik. Jurnal Pengabdian Dan Pemberdayaan Masyarakat, 3 (1). 